\title{
Nectar secretion of Callistemon citrinus (Curtis) Skeels, Myrtaceae: Potential for honey production
}

\author{
Tura Bareke*, Tesfaye Abera and Admassu Addi \\ Oromia Agricultural Research Institute, Holeta Bee Research Center, Ethiopia \\ *Corresponding Author: trbareke@gmail.com
}

\begin{abstract}
The honey production capacity of bee flora is used to estimate the optimum colony carrying capacity of given area that helps to harvest the best honey yield. The research was conducted to quantify the nectar secretion pattern, the effect of temperature and humidity on dynamics of nectar secretion, and honey production capacity of Callistemon citrinus. One day before nectar collection, five inflorescences were enclosed with mesh bags on different branches of the tree. From these, twenty flowers were randomly selected per tree for the measurement of nectar volume. Additionally, nectar volume and concentration, temperature, and air humidity were measured with an interval of one hour. One way ANOVA and linear regression were used for data analysis. The average amount of nectar and its concentration were different significantly within the time of the day. Nectar amount was correlated positively with humidity while concentration was negatively correlated with temperature. The average nectar volume ( $\mu 1)$ per flower in 24 hours, sugar amount per tree $(\mathrm{kg})$, honey yield per individual tree $(\mathrm{kg})$ and honey production capacity of Callistemon citrinus per hectare were $10.9 \pm 0.4,0.65,0.79$, and $1264 \mathrm{~kg}(46-3808 \mathrm{~kg})$, respectively. The real expected honey yield was $632 \mathrm{~kg}$ ha ${ }^{-1}$. Total financial return was estimated to be $\$ 4424$ based on a value of $\$ 7 \mathrm{~kg}^{-1}$ of Callistemon citrinus honey. Therefore, the multiplication and plantation of this plant are suggested for honey production.
\end{abstract}

Keywords: Nectar, Volume, Concentration, Honey potential, Temperature, Humidity.

\section{INTRODUCTION}

Beekeeping is an economic incentive for the conservation of forest and is an ideal activity in watershed conservation programs (Addi et al., 2014; Kumsa, 2014; Bareke et al., 2014). Beekeeping encouraged tree planting that creates a suitable microclimate and which is indirectly used to alleviate the problem of climate change. Moreover improved beekeeping technologies have a great contribution to create job opportunities for jobless people. Generally, to integrate the honey production with the conservation of forest and watershed, examination of honey production capacity of bee plants is very essential to determine the optimum honeybee colony carrying capacity of plant species. Estimating the number of honeybee colonies with an existing resource is used to increase the yield of honeybee colonies for alleviating the problem of colony overstocking (Al-Ghamdi et al., 2016; Bareke et al., 2020).

The honey production capacity of bee plants is estimated using the nectar volume and concentration (Bareke et al., 2020). Nectar is an aqueous solution that attracts pollinators. It is secreted by floral nectaries and used for honey production due to its sugar concentration, volume, and chemical composition (Galetto et al., 1997; Galetto \& Bernardello, 2004; McDade \& Weeks, 2004). Nectar composition, mainly amino acids and sugar, which may influence pollinator attraction and fidelity (Bertazzini \& Forlani, 2016). Nectar secretion pattern is also greatly influenced by biotic and abiotic factors (Jakobsen \& Kristjansson, 1994; Petanidou et al., 1996; Burkle \& Irwin, 2009; Bareke et al., 2020). Hence, the knowledge of bee plants and nectar secretion potential is very important to understand the plantanimal relationship (Galetto \& Bernardello, 2004). Bee floral is those plant species that supply nectar and/or pollen for honeybees (Addi et al., 2014; Bareke \& Addi, 2018; Addi \& Bareke, 2019). The honey production potential of bee floral species is affected by the quality and quantity of nectar secretion (Adgaba et al., 2017).

Based on the nectar excretion potential of the floral, many authors determined their honey production potential (Wolff, 2006; Kim et al., 2011; Adgaba et al., 2012; Witt et al., 2013; Abdulaziz et al., 2015; Adgaba et al., 2016; Bareke et al., 2020). However, there are many important bee plant species that are not known for their nectar excretion and honey production capacity. This includes Callistemon citrinus which is one of the ornamental melliferous species. Callistemon citrinus is a small tree with numerous floppy branches that belongs to the family Myrtaceae (Bareke et al., 2017). It is planted as an ornamental plant in parks and homegardens at altitudes from 1200 to $2500 \mathrm{~m}$. It is widely distributed in Kefa, Shewa, Sidamo, and Harerge floristic regions. Callistemon citrinus is native to New South Wales and Victoria in Australia (Fichtl \& Addi, 1994). 
Callistemon citrinus usually flowers throughout the year. It is widely planted in Ethiopia for honeybee production and as an ornamental plant. However, the plant is flowered mostly after the rainy season (Fichtl \& Addi, 1994; Bareke et al., 2017). Callistemon citrinus starts blooming from the base of the branch and goes to the end of the branches. It supplies an adequate amount of pollen (for brood rearing) and nectar (for honey production) for honeybees. However, the nectar secretion pattern and honey production capacity of Callistemon citrinus are not yet determined. Hence, the purpose of this study was to investigate the nectar excretion pattern, honey production capacity per tree, honey production per hectare of Callistemon citrinus plantation.

\section{MATERIALS AND METHODS}

\section{Materials used}

- Micropipettes was used to collect nectar

- Micropipettes' tips

- Digital refractometer was used to measure nectar concentration

- Hygrometer was used to measure temperature and humidity at the same time

- Ladder was used to climb the plant for data collection

- Mesh bags cover the flowers branch

\section{Study site}

The experiment was undertaken in Walmera District, Oromia Region, Ethiopia. The major rainy season for the study area starts June to September and means annual precipitation was $1150 \mathrm{~mm}$ (Bareke et al., 2018). Red soil is the major soil type in the study area. Callistemon citrinus was selected based on the honeybee visiting intensity, flowering duration and convenience of flower for nectar measurement using a micropipette.

\section{Phenology}

To identify the anther dehiscence and nectar excretion time, an observation was taken from three plants. Five flowers were labeled from each plant, and a total of 15 flowers were taken for observation (Bareke et al., 2020).

\section{Determining individual flower heads per plant}

Many flowered trees with massive flowers (Fig. 1) were purposively selected from the smallest to large. From this, twenty productive plants were randomly selected to get the mean number of flowers per individual plant.

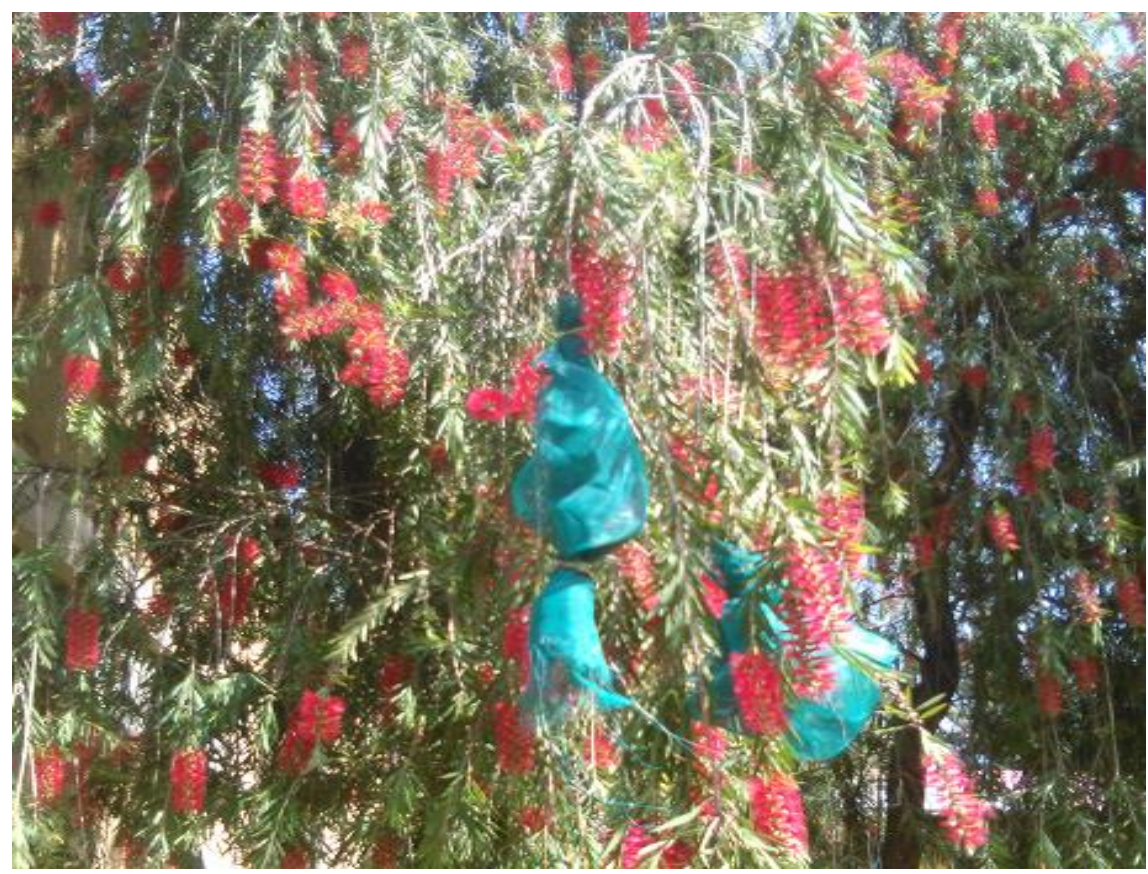

Figure 1. Callistemon citrinus (Curtis) Skeels.

\section{Determination of nectar volume}

One day before nectar measuring, five (5) inflorescences were enclosed with mesh net on different branches of the individual plant (Wyatt et al., 1992; Bareke et al., 2020). Fifteen plants were received for nectar measurement. Twenty (20) flowers per individual plant were randomly selected for nectar collection. The amount of nectar secreted in 24 hours was measured from 100 flowers using 0.5-10 $\mu 1$ micropipettes. 


\section{Investigation of nectar excretion dynamics of Callistemon citrinus}

Data of nectar volume, nectar concentration, temperature and humidity were taken at one hour interval from 7:0018:00 hours simultaneously. Nectar concentration was measured using digital refractometer while temperature and humidity was measured using hygrometer. Nectar was collected from three flowers at each time measurement for 5 consecutive days ( 3 Flowers*12 times*5 days=180 flowers). Additionally, to determine the nectar secretion duration of C. citrinus, 5 individual flowers were measured daily from the start to end of nectar secretion (Bareke et al., 2020).

\section{Determination of nectar sugar quantity}

Nectar sugar quantity was calculated using nectar concentration, nectar volume, and sucrose density. The readings of digital refractometers are in sucrose equivalents that were taken as milligrams of sugar per100 mg of solution (Dafni, 1992; Bareke et al., 2020). These readings were converted to milligrams of sugar per flower. The measured sucrose equivalent was converted to $\mathrm{g}^{-1}$ and multiplying this value by the nectar amount (Bolten et al., 1979). Prys-Jones \& Corbet (1987) equation was used to convert sucrose concentration to density. Dafni (1992) equation was used to estimate the amount of sugar.

\section{Estimation of honey production capacity}

The honey production capacity of Callistemon citrinus was estimated as the following: The mean of flower heads per individual plant * the mean amount sugar per individual flower head* nectar secretion length $=$ average amount of sugar per tree/flowering season (Bareke et al., 2020). The mean amount of sugar per individual plant was converted to honey.

At the international market the average moisture content of the honey is $18 \%$ from $1 \mathrm{~kg}$ while $82 \%$ is sugar. This was used to convert the mean amount of sugar produced per individual plant per flowering season to honey. The recommended space required per individual plant species was used to estimate the number of plants per hectare of land.

\section{Data analysis}

One-way ANOVA was used for data analysis. Homogeneity of the data was checked by Levene tests. Mean separation among the treatments were performed using Tukey multiple comparison test. In addition to this, linear regression model was used to see the effect of temperature and humidity on nectar volume and concentration.

\section{RESULTS}

\section{Nectar secretion length}

The nectar volume of Callistemon citrinus was significantly different between the start and the end of the secretion date (Fig. 2). The peak nectar secretion was recorded on the day 3 (D3) while the lowest was at the end of secretion. As the age of the flower increased, the amount of nectar secreted decreased.

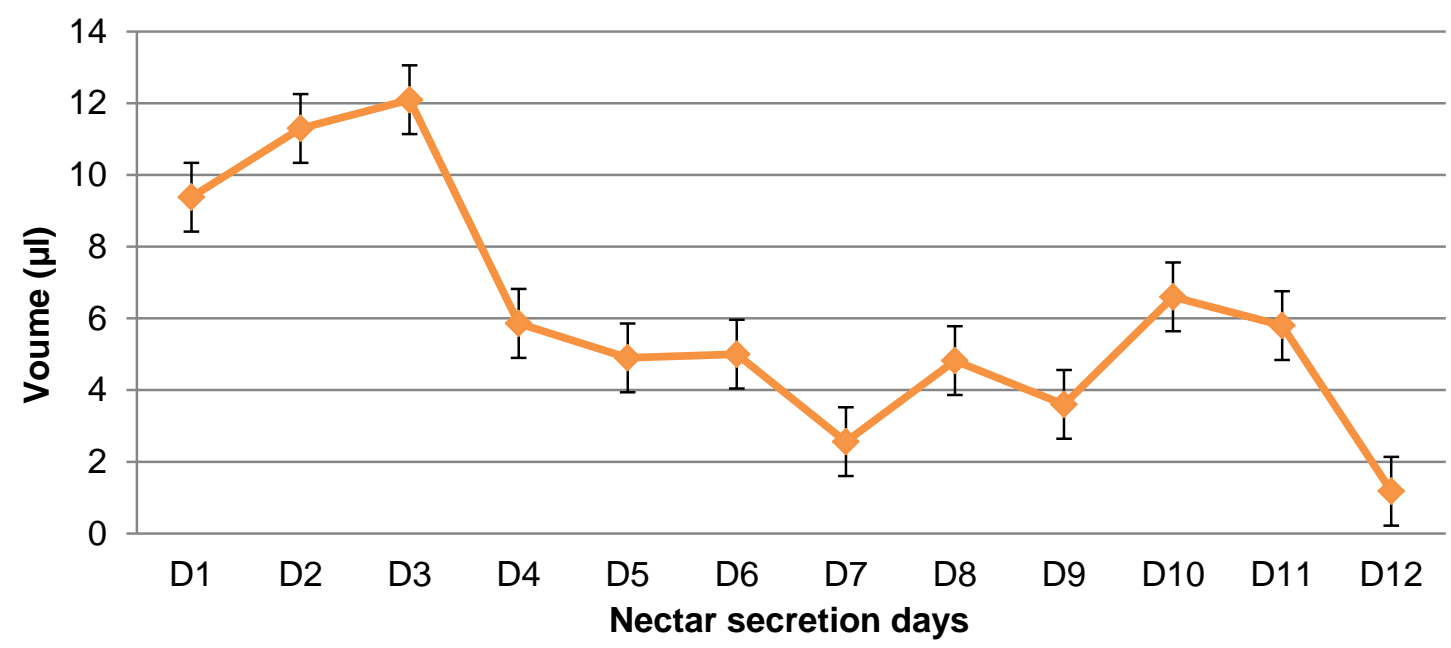

Figure 2. Nectar secretion length and volume of Callistemon citrinus (Curtis) Skeels. flower from start of secretion to end (repeated collection daily) ( $\mathrm{N}=5$ flowers daily from the start to end) $\mathrm{D}$ : day, \pm Error bars with standard error.

\section{Nectar secretion dynamicys}

The mean nectar concentration and volume were significantly different across times of the days $(p<0.05)$. The highest nectar volume was found between 6:00 am to 7 am followed by 7-8:00 am while the lowest average nectar volume recorded at 16:00 pm. Early in the morning the humidity of the area was the highest. Due to this, the highest nectar volume was recorded in the morning. The highest nectar concentration value was found between 12:00 and 13:00 hours whereas the lowest concentration was secreted between 6:00 and 7:00 hours (Table 1). 
Table 1. Mean nectar volume $(\mu \mathrm{l})$ per flower and nectar concentration $(\%)$ at 1 hour interval per flower with \pm standard error (SE) of Callistemon citrinus (Curtis) Skeels from 7:00 to 18:00 hours of the day.

\begin{tabular}{lrr}
\hline Time (hour) & Average nectar volume $(\boldsymbol{\mu l}) \pm \mathbf{S E}$ & Average nectar concentration at 1hr intervals \\
\hline $7: 00$ & $14.00 \pm 1.20^{\mathrm{a}}$ & $10.72 \pm 1.83^{\mathrm{d}}$ \\
$8: 00$ & $12.10 \pm 1.00^{\mathrm{ab}}$ & $12.84 \pm 2.28^{\mathrm{cd}}$ \\
$9: 00$ & $11.50 \pm 1.40^{\mathrm{ab}}$ & $13.24 \pm 2.04^{\mathrm{cd}}$ \\
$10: 00$ & $8.90 \pm 0.60^{\mathrm{ab}}$ & $18.06 \pm 3.62^{\mathrm{bcd}}$ \\
$11: 00$ & $11.70 \pm 1.90^{\mathrm{ab}}$ & $21.66 \pm 4.96^{\mathrm{abc}}$ \\
$12: 00$ & $9.40 \pm 2.30^{\mathrm{ab}}$ & $18.26 \pm 3.05^{\mathrm{bcd}}$ \\
$13: 00$ & $7.60 \pm 1.10^{\mathrm{b}}$ & $29.44 \pm 3.06^{\mathrm{a}}$ \\
$14: 00$ & $7.90 \pm 1.20^{\mathrm{b}}$ & $28.08 \pm 2.11^{\mathrm{ab}}$ \\
$15: 00$ & $10.4 \pm 2.30^{\mathrm{ab}}$ & $24.68 \pm 3.03^{\mathrm{ab}}$ \\
$16: 00$ & $6.96 \pm 0.85^{\mathrm{b}}$ & $27.88 \pm 2.63^{\mathrm{ab}}$ \\
$17: 00$ & $9.68 \pm 1.88^{\mathrm{ab}}$ & $27.12 \pm 5.31^{\mathrm{ab}}$ \\
$18: 00$ & $9.06 \pm 2.25^{\mathrm{ab}}$ & $18.74 \pm 3.30^{\mathrm{bcd}}$ \\
\hline
\end{tabular}

Note: Different letters show significant differences.

The effect of temperature and humidity on nectar secretion of Callistemon citrinus (Curtis) Skeels.

During the study period, air humidity was found in the range of $25-75 \%$ whereas the temperature of the day was in the range of $13.5-30.6^{\circ} \mathrm{C}$. The peak nectar volume was found at the lowest temperature and in the highest values of humidity. This shows the indirect relationships of nectar volume with temperature as well as the direct relationship of nectar volume with humidity (Figs. $3 \& 4$ ). As the temperature increased the nectar volume decreased. However, the peak nectar secretion temperature was between $20^{\circ} \mathrm{C}$ and $25^{\circ} \mathrm{C}$ for Callistemon citrinus. On the other hand, nectar volume is increased as the humidity of the area increased.

The highest value of nectar concentration was recorded between $20^{\circ} \mathrm{C}$ and $25^{\circ} \mathrm{C}$ temperatures while the lowest was at less than $20^{\circ} \mathrm{C}$ (Fig. 3). The highest nectar concentration value was recorded between $50 \%$ and $60 \%$ humidity whereas the lowest recorded above $60 \%$ (Fig. 4).

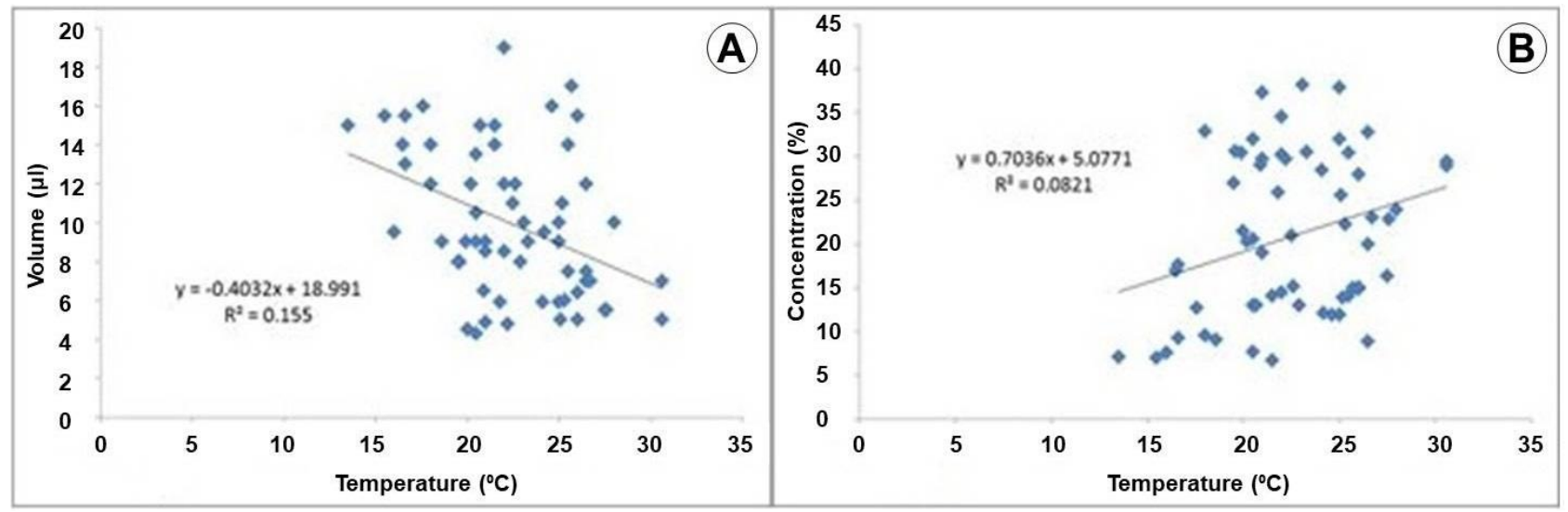

Figure 3. Effect of temperature on Callistemon citrinus (Curtis) Skeels: A, Nectar volume; B, Concentrations.

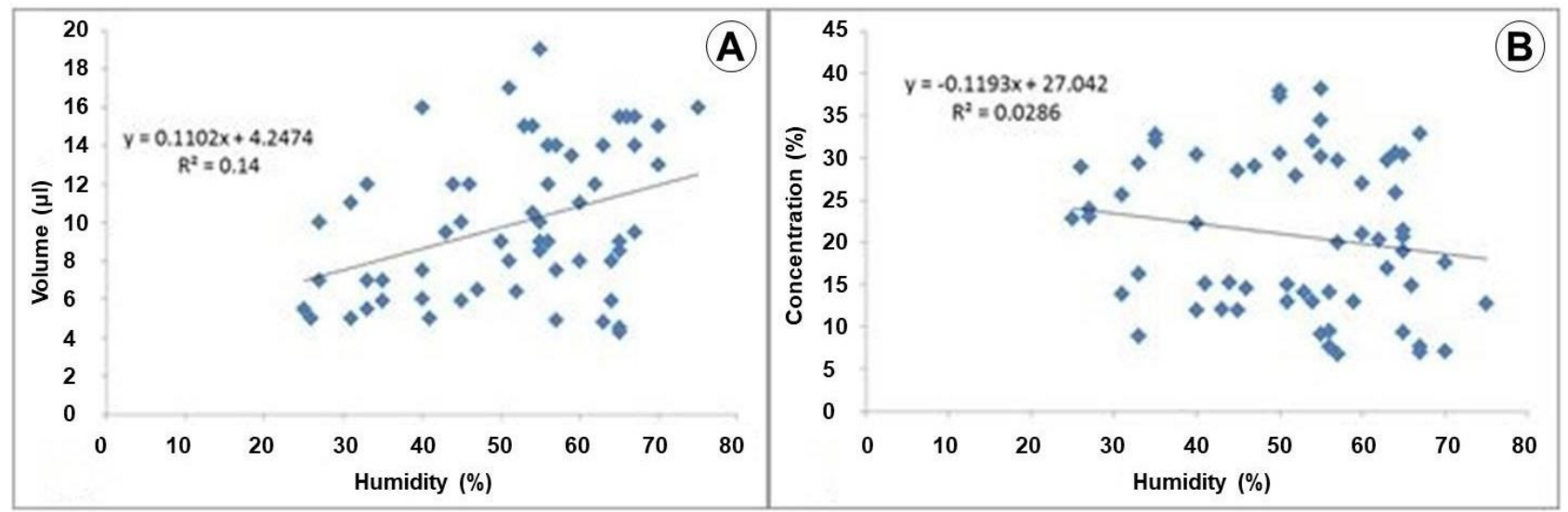

Figure 4. Effect of humidity on Callistemon citrinus (Curtis) Skeels: A, Nectar volume; B, Concentrations.

\section{Honey production potential of Callistemon citrinus}

The average number of Callistemon citrinus flowers per plant was 31000 (Table 2). The blooming length of Callistemon citrinus was 11-15 days. However, it provides nectar to insect pollinator from 10 to 12 days. The average 
amount of sugar per flower/season was $21 \pm 1.3 \mathrm{mg}$ (range 7.6-63. mg), therefore, the mean amount of estimated sugar per plant was $0.65 \mathrm{~kg}(0.024 \mathrm{~kg}$ to $1.95 \mathrm{~kg})$.

Table 2. Mean number flower heads/plant ( $=20$ plant), mean nectar volume in 24 hours $(\mu 1)(\mathrm{N}=100$ flowers $)$ and mean sugar amount per flower life cycle (mg) ( $\mathrm{N}=100$ flowers) of Callistemon citrinus (Curtis) Skeels.

\begin{tabular}{lrrr}
\hline Treatments & Mean \pm SE & Minimum & Maximum \\
\hline Mean number flower heads/plant & $31000 \pm 4506$ & 2740 & 92160 \\
Mean Nectar volume in 24 hours $(\mu 1) / f l$ lower & $10.9 \pm 0.40$ & 0.70 & 20 \\
Mean sugar amount per flower life cycle $(\mathrm{mg})$ & $21.1 \pm 1.35$ & 7.62 & 63.05 \\
\hline
\end{tabular}

The moisture content of honey is $18 \%$ whereas $82 \%$ is sugar. The average amount of sugar per individual plant of Callistemon citrinus $(0.65 \mathrm{~kg})$ per season was $0.79 \mathrm{~kg}$ of honey $(0.029-2.38 \mathrm{~kg})$. Recommended space for Callistemon citrinus plantation was $2.5 \mathrm{~m}$ and, the total individual of Callistemon citrinus plants per hectare of land was 1600 . Therefore, the mean honey production capacity of Callistemon citrinus plantation would be $1264 \mathrm{~kg}$ (46-3808 kg) from one hectare per flowering season. The real harvestable amount of honey was $632 \mathrm{~kg} \mathrm{ha}^{-1}$ which is half of the potential of the species.

\section{Financial implication from a hectare of Callistemon citrinus (Curtis) Skeels through honey production potential}

The expected harvestable honey yield from a hectare of productive trees of Callistemon citrinus with the massive flowers was $632 \mathrm{~kg}$. If a kilogram of Callistemon citrinus honey is valued 200 Ethiopian Birr (ETB) or \$7, the total financial to be expected is $632 \mathrm{~kg} * 200 \mathrm{ETB}=126400 \mathrm{ETB}$ or $4424 \$$ per hectare of Callistemon citrinus plants. This indicates how much this plant is economically valuable in honey production.

\section{DISCUSSION}

Callistemon citrinus provide nectar for 10 to 12 days. On the other hand, Coffea arabica L. secret nectar for 5 days (Bareke et al., 2017) and Croton macrostachyus Del.averagely secret for 8 days (Bareke et al., 2020). The nectar secretion length is varied from plant species to species. Nectar secretion capacity of both bagged- and exposed flowers were decreased after the removal during the entire flower lifetime (Chauhan et al., 2017). The nectar secretion variability between flowers on the same plant is due to position on the flowering stem to the microclimate of the area (Jakobsen \& Kristjansson, 1994, Macukanovic et al., 2004; Stevenson et al., 2017). Additionally, daily weather variation and other environmental factors may cause shifts in the pattern of nectar characteristics, morphological and phenological characteristics that affect the nectar secretion amount of bee plants (Kaczorowski et al., 2014; Parachnowitsch et al., 2019).

Many flowering plants are provided nectar to attract pollinators, reflecting that the co-evolution between the plants and their pollinators (Ning-Na et al., 2015; Power et al., 2018). The common nectar variables relevant to pollination are its concentration, volume and sugar. Nectar is not part of the plant's sexual system but a reward offered to a foraging agent. The nectar collection method is affected by flower size, inflorescence size, nectar volume and nectar concentration (Dafni, 1992; Parachnowitsch et al., 2019). Micropipettes is widely used for nectar volume collection for which volume is $>0.5 \mu \mathrm{l}$ and concentration $<70 \%$. Nectar collection from small flowers needs special techniques (Dafni, 1992).

Callistemon citrinus provides nectar from 7:00-18:00 hours of the day time. Similarly, study conducted on Ziziphus spina-christi (L.) Desf. and Lavender species also indicate that these species provide nectar the whole day (Adgaba $e t$ al., 2012; Adgaba et al., 2015). On the other hand, Croton macrostachyus secret nectar from 8:00 to15:00 (Bareke et al., 2020). Nectar secretion variations by the different bee plants could be due to the variations in flower size the plant species, temperature, water availability, humidity, light and nutrients (Burkle \& Irwin, 2009; Al-Ghamdi et al., 2016; Parachnowitsch et al., 2019).

Nectar volume of Callistemon citrinus has direct relation with humidity and indirect relation with the temperature of the study area. The nectar volume of Croton macrostachyus also has indirect relationships with the temperature of the study area (Bareke et al., 2020). However, study conducted by Kim et al. (2017) on Crataegus pinnatifida Bunge in Korea and Chinese indicates that nectar volume was positively correlated with both temperature and air humidity. This shows the effect of environmental factors on the amount of nectar secreted is varied from plant species to species.

The peak of temperature overlapped with the lowest relative humidity, indicating an inverse relationship between the two environmental factors. The study conducted by Adjaloo et al. (2015) on Antigonon leptopus Hook. \& Arn. and Theretia peruviana (Pers.) K. Schum were also indicated that the nectar concentration was negatively correlated with the humidity. The study conducted on Thymus capitatus (L.) Hoffmanns (Petanidou \& Smets, 1996) and Croton macrostachyus (Bareke et al., 2020) indicate that their nectar concentration have positively correlated with temperature. Additionally, the nectar concentration of Lavandula dentata L. and Lavandula pubescens Decne (LP) were positively 
correlated with an increase in temperature of the area (Adgaba et al., 2015). On the other hand, the amount of nectar in Lavandula dentata was positively correlated with in relative humidity. But, for Lavandula pubescens the nectar volume was decreased as relative humidity increased.

The real amount of honey that can be harvested from the hive is below the estimated amount. Honeybees consume a certain amount of sugar for their flight energy during nectar collection and transportation to the hives. In addition to this, all the nectar secreted may not be accessible to honeybees due to quick crystallization of nectar. The honey production potential of Callistemon citrinus (46-3808 $\mathrm{kg} \mathrm{ha}^{-1}$ ) was found in similar range with the different annual plants and trees such as Croton macrostachyus in range of 234-1770 $\mathrm{kg} \mathrm{ha}^{-1}$ (Bareke et al., 2020), Lime species (Tilia spp.) (90 to $1200 \mathrm{~kg} \mathrm{ha}^{-1}$ ) (Crane et al., 1984), and Ziziphus spina-christi (550-1300 kg ha ${ }^{-1}$ ) (Adgaba et al., 2012), Brassica juncea (L.) Czern. and Sinapis alba L. crops $65.5 \mathrm{~kg}$ and $71.2 \mathrm{~kg} \mathrm{ha}^{-1}$, respectively (Masierowska, 2003).

The numbers of honeybee colonies required to be located in a hectare of plants were varies depending on the kinds of beehives. Harmonizing several honeybee colonies with the available resource is used to harvest optimum by overcoming the problem of colony overstocking (Al- Ghamdi et al., 2016; Adgaba et al., 2017). The ideal distribution of honeybee colonies reduces the overstocking to utilize the existing floral resources around the apiary (Esteves et al., 2010).

\section{CONCLUSION}

Our study suggests that Callistemon citrinus has a good capacity to provide nectar that significantly contributes to honey production. Nectar volume and concentration of Callistemon citrinus were affected by both temperature and humidity. Nectar volume and concentration were significantly different in times of the day. One hectare of Callistemon citrinus plants have a capacity to give $1264 \mathrm{~kg}$ of honey while the actual honey to be harvested per hectare was $632 \mathrm{~kg}$. From expected honey to be harvested from a hectare of Callistemon citrinus plants, $4424 \$$ would be obtained from honey sales. Therefore, the multiplication and management of Callistemon citrinus is recommended for honey production and soil protection.

\section{ACKNOWLEDGEMENTS}

We acknowledge the Holeta Bee Research Center and Oromia Agricultural Research Institute for providing required facilities and logistics.

\section{REFERENCES}

Abdulaziz S.A., Awad M.A. \& Ayman A.O. (2015). Evaluation of Acacia gerrardii. (Fabaceae: Mimosoideae) as a honey plant under extremely hot-dry conditions: Flowering phenology, nectar yield and honey potentiality. The Journal of Animals and Plant Sciences, 25(6): 1667-1674.

Addi A., Wakjira K. \& Bareke T. (2014). Case study on contribution of beekeeping to the income generation of the households bordering Menagesha Suba State Forest. Retrieved from: http://www.apitradeafrica.org/Documents/Technical Papers

Addi A. \& Bareke T. (2019). Review : Floral resources diversity of honeybees in important types of vegetation of Ethiopia. Asian Journal of Forestry, 3(2): 64-68.

Adgaba N., Al-Ghamdi A.A., Tena Y.T., Shenkut A.G., Ansari M.J. \& Al-Maktary A. (2015). Floral phenology, nectar secretion dynamics, and honey production potential, of two lavender species (Lavandula dentata, and L. pubescens) in southwestern saudi arabia. Journal of Apicultural Science, 59(2): 135-144.

Adgaba N., Ahmed A.A., Shenkute G.A., Mohammed A., Mohammed J.A., Rachid S. \& Sarah E.R. (2016). Pollination ecology, nectar secretion dynamics, and honey production potentials of Acacia ehrenbergiana (Hayne) and Acacia tortilis (Forsk.) Hayne, Leguminosae (Mimosoideae), in an arid region of Saudi Arabia. Tropical Ecology, 57(3): 429-444.

Adgaba N., Al-ghamdi A., Tadesse Y., Getachew A., Awad A.M., Ansari M.J. \& Alqarni A.S. (2017). Nectar secretion dynamics and honey production potentials of some major honey plants in Saudi Arabia. Saudi Journal of Biological Science, 24(1): 180191.

Adgaba N., Awad A.M., Al-Ghamdi A.A., Alqarni A.S. \& Radloff S.E. (2012). Nektar Ziziphus spina-christi (L.) Willd (Rhamnaceae): Dynamika Nektarowania I Wydajność Miodowa. Journal of Apicultural Science, 56(2): 49-59.

Adjaloo M., Ankomah A., Yeboah-Gyan K. \& Dzomeku B. (2015). Nectar production dynamics in two melliferous plant species. Genetic and Plant Physiology, 5(2): 145-161.

Al-Ghamdi A., Adgaba N., Getachew A. \& Tadesse Y. (2016). New approach for determination of an optimum honeybee colony's carrying capacity based on productivity and nectar secretion potential of bee forage species. Saudi Journal of Biological Science, 23(1): 92-100.

Bareke T.K., Addi A.M. \& Wakjira K.H., (2014). Investigating the role of apiculture in watershed management and income improvement in Galessa protected area, Ethiopia. Agriculture, Forestry and Fisheries, 3(5): 380-385.

Bareke T. \& Addi A. (2018). Honeybee Flora Resources of Guji Zone, Ethiopia Honeybee Flora Resources of Guji Zone, Ethiopia. Journal of Biology, Agriculture and Healthcare, 8(21): 1-9.

Bareke T., Addi A. \& Wakjira K. (2017). Screening of Potential Shrubs for Bee Forage Development. Journal of Plant Sciences, 
5(5): 160-164.

Bareke T., Addi A. \& Wakjira K. (2018). Role and Economic Benefits of Honey bees' Pollination on Fruit Yield of Wild Apple (Malus sylvestris (L.) Mill.) in Central Highlands of Ethiopia. Bee World, 95(4): 113-116.

Bareke T., Kumsa T., Roba K. \& Addi A. (2020). Nectar secretion dynamics and honey production potential of Croton macrostachyus L., Euphorbiaceae. Bee World, 97(4): 123-127.

Bertazzini M. \& Forlani G. (2016). Intraspecific Variability of Floral Nectar Volume and Composition in Rapeseed (Brassica napus L.var. oleifera). Frontier Plant Sciences, 7: 288. [DOI: 10.3389/fpls.2016.00288]

Bolten A.B., Feinsinger P., Baker H.G. \& Baker I. (1979). On the calculation of sugar concentration in flower nectar. Oecologia, 304: 301-304.

Burkle L.A. \& Irwin R.E. (2009). The effects of nutrient addition on floral characters and pollination in two subalpine plants, Ipomopsis aggregata and Linum lewisii. Plant Ecology, 203: 83-98.

Chauhan S., Chauhan S.V.S. \& Galetto L. (2017). Floral and pollination biology, breeding system and nectar traits of Callistemon citrinus (Myrtaceae) cultivated in India. South African Journal of Botany, 111: 319-325.

Crane E., Walker P. \& Day R. (1984). Directory of Important World Honey Sources. International Bee Research Association, London, pp. 384.

Dafni A. (1992). In: Rickwood D.B. \& Hames D. (Eds.) Book-Pollination Ecology-A Prctical Approcach A.dafni optimized. Oxford University Press.

Esteves R.P., Villadelrey M.C. \& Rabajante J.F. (2010). Determining the optimal distribution of bee colony locations to avoid overpopulation using mixed integer programming. Journal of Nature Studies, 9(1): 79-82.

Fichtl R. \& Addi A. (1994). Honeybee Flora of Ethiopia. Margraf Verlage, Germany, pp. 510.

Galetto C., Bernardello G. \& Rivera G.L. (1997). Nectar, Nectaries, Flower Visitors, and Breeding System in Five Terrestrial Orchidaceae from Central Argentina. Journal of Plant Research, 110: 393-403.

Galetto L. \& Bernardello G. (2004). Floral Nectaries, Nectar Production Dynamics and Chemical Composition in Six Ipomoea Species (Convolvulaceae) in Relation to Pollinators. Annals of Botany, 94: 269-280.

Jakobsen H.B. \& Kristjansson K. (1994). Influence of temperature and floret age on nectar secretion in Trifolium repens L. Annals of Botany, 74: 327-334.

Kaczorowski R.L., Koplovich A., Sporer F., Wink M. \& Markman S. (2014). Immediate effects of nectar robbing by Palestine Sunbirds (Nectarinia osea) on nectar alkaloid concentrations in Tree Tobacco (Nicotiana glauca). Journal of Chemistry and Ecology, 40: 325-330.

Kim S.H., Lee A., Kang D., Kwon H.Y., Park Y. \& Kim M.S. (2017). Análisis de características de néctar floral de espino blanco coreano y chino (Crataegus pinnatifida Bunge). Journal of Apicultural Research, 57(1): 119-128.

Kim M.S., Kim S.H., Han J., Kang M.S. \& Park Y.K. (2011). Honey bee visit and nectar secretion characteristics of the Chinese Hawthorn Crataegus pinnatifida Bunge. Journal of Apicultural Science, 26(1): 11-14.

Kumsa T.G. (2014). Integrating Improved Beekeeping as Economic Incentive to Community Watershed Management: The Case of Sasiga and Sagure Districts in Oromia Region, Ethiopia. Agriculture, Forestry and Fisheries, 3(1): 52-57.

Macukanovic M., Duletic S. \& Jocic G. (2004). Nectar production in three melliferous species of Lamiaceae in natural and experimental conditions. Acta Veterinaria Beograde, 54(5-6): 475-487.

McDade L.A. \& Weeks J. (2004). Nectar in humming bird pollinated neotropical plants I: Patterns of production and variability in 12 species. Biotropica, 36: 196-215.

Masierowska M.L. (2003). Floral nectaries and nectar production in brown mustard (Brassica juncea) and white mustard (Sinapis alba) (Brassicaceae). Plant Systematic and Evolution, 238: 97-107.

Ning-Na L., Xiao-Hui L., Lin L \& Zhi-Gang Z. (2015). Variation of nectar production in relation to plant characteristics in protandrous Aconitum gymnandrum. Journal of Plant Ecology, 8(2): 122-129.

Parachnowitsch A.L., Manson J.S. \& Sletvold N. (2019). Review: Part of a Special Issue on Ecology and Evolution of Plant Reproduction. Evolutionary ecology of nectar. Annals of Botany, 123: 247-261.

Petanidou T. \& Smets E. (1996). Does temperature stress induces nectar secretion in Mediterranean plants? New Phytology, 133: 513-518.

Petanidou T., Van Laere A.J. \& Smets E. (1996). Change in floral nectar components from fresh to senescent flowers of Capparis spinosa (Capparidaceae) a nocturnally flowering Mediterranean shrub. Plant Systematic and Evolution, 199(1-2): 79-92

Power E.F., Stabler D., Borland A.M., Barnes J. \& Wright G.A. (2018). Analysis of nectar from low-volume flowers: A comparison of collection methods for free amino acids. Methods in Ecology and Evolution, 9: 734-743.

Prys-Jones O.E. \& Corbet S.A. (1987). Bumblebees: Naturalists' Handbooks 6. The Richmond Publishing Co. Ltd, Slough.

Stevenson P.C., Nicolson S.W. \& Wright G.A. (2017). Plant secondary metabolites in nectar: impacts on pollinators and ecological functions. Functional Ecology, 31: 65-75.

Witt T., Juergens A., \& Gottsberger G. (2013). Nectar sugar composition of European Caryophylloideae (Caryophyllaceae) in relation to flower length, pollination biology and phylogeny. Journal of Evolution and Biology, 26: 2244-2259.

Wolff D. (2006). Nectar sugar composition and volumes of 47 species of Gentianales from a Southern Ecuadorian montane forest. Annals of Botany, 97: 767-777.

Wyatt R., Broyles S.B. \& Derda G. (1992). Environmental influences on nectar production in milkweeds (Ascelapias syriaca and A. exaltata). American Journal of Botany, 79: 636-642. 